Scientia Agricola

http://dx.doi.org/10.1590/0103-9016-2014-0321

\title{
In-vitro screening of Kalahari browse species for rumen methane mitigation
}

\author{
Jacobus Johannes Francois Theart ${ }^{1}$, Abubeker Hassen ${ }^{1}$, Willem Adriaan van Niekerk ${ }^{1}$, Belete Shenkute Gemeda
}

${ }^{1}$ University of Pretoria - Dept of Animal and Wildlife Sciences, Private Bag, 0002 - Hatfield, Pretoria - South Africa.

*Corresponding author <Abubeker.hassen@up.ac.za>

Edited by: Paulo Cesar Sentelhas

Received October 07, 2014

Accepted June 22, 2015

\section{Introduction}

Methane is among the most important greenhouse gases responsible for a significant loss of energy by the ruminant through enteric methane $\left(\mathrm{CH}_{4}\right)$ fermentation (Jayanegara et al., 2011). Livestock, especially ruminants, contribute to $\mathrm{CH}_{4}$ emissions through enteric fermentation and fermentation also taking place in the manure. This is especially the case when feeding highly fibrous diets which are prevalent in the tropics. In this regard, inclusion of feeds containing plant secondary metabolites, such as tannin in diets of ruminants, seems promising as a nutritional strategy to reduce $\mathrm{CH}_{4}$ emissions from ruminants (Sebata et al., 2011; Sultan et al., 2012).

Tannins are polyphenolic compounds which bind to protein and act as chemical additives for protecting and decreasing ruminal degradation of proteins in ruminant feeds. Earlier studies suggested that feeding forages that contain tannins for ruminants generally effectively inhibit $\mathrm{CH}_{4}$ produced during enteric fermentation (Puchala et al., 2005). In this regard, tannins of lower molecular weights were found to be more effective against methanogens than their monomeric precursors or tannins of higher molecular weight (Tavendale et al., 2005). However, there is huge diversity in tannin structure and concentration, and other chemical constituents among the browses, which may affect variably, the observed response in rumen fermentation, digestibility of nutrients and methanogen activity (Mueller-Harvey, 2006). This indicates that tannin from different plants might show a different response in gas production, true digestibility and methane production. The objective of this study was to investigate variations among palatable browse species foliage collected from the Kalahari bush dune veld in South Africa in terms of gas production characteristics, forage digestibility, VFA, ammonia-nitrogen $\left(\mathrm{NH}_{3}-\mathrm{N}\right)$ and $\mathrm{CH}_{4}$ production. The single effect of tannin was also studied and quantified for each browse species by incubating the browse plants with or without polyethylene glycol (PEG).

\section{Materials and Methods}

\section{Study area description}

Browse foliage sample collection for this study was carried out in the North West Province of South Africa in the Thorny Kalahari Dune Bush veld with an altitude of about 900 to $1100 \mathrm{~m}$ above sea level. The soil is sandy to sandy loam, and has excessive drain with high base status dunes that contain elevated concentrations of copper, which are bound in the soil in the form of secondary copper hydroxyl mineral atacamite $\left(\mathrm{Cu}_{2}(\mathrm{OH})_{3} \mathrm{Cl}\right)$. The area has highly erratic rainfall that ranges from 150 to $350 \mathrm{~mm}$ per year; however, it has barely exceeded $150 \mathrm{~mm}$ per year for the last two years and during the study period. The wettest months are usually from January to April and the extreme 
temperatures range from a winter low reaching $-10.3^{\circ} \mathrm{C}$ to summer highs of up to $45.4^{\circ} \mathrm{C}$ (Van Rooyen, 2001).

\section{Sample collection, preparation and chemical analysis}

Samples of nineteen tannin rich browse plants (Table 1) were collected during the summer rainy season (Feb 2012). In this study, a shrub was considered as a small to medium-sized woody plant and distinguished from a tree by its multiple stems and shorter height, usually under $6 \mathrm{~m}$ tall. The browses were harvested at the same time when they were at the same maturity stage; almost at early vegetative stage. Fresh foliages (leaves and stems $<3 \mathrm{~mm}$ diameter) were harvested from at least five randomly selected and tagged representative plants of each species. During the sampling, fresh plant leaves and twigs (less than $3 \mathrm{~mm}$ in stem diameter) were hand plucked from 19 browse species to be used. Samples were dried at $55{ }^{\circ} \mathrm{C}$ for $48 \mathrm{~h}$ in a forced oven and ground to pass through a $1 \mathrm{~mm}$ sieve in a Wiley mill and used for chemical analysis. The neutral detergent fiber (NDF), acid detergent fiber (ADF) and acid detergent lignin (ADL) contents were determined using 200/220 Fiber Analyzer according to the methodology described by van Soest et al. (1991). Sodium sulphite and heat-stable amylase were used in an analysis of NDF. Nitrogen was analyzed following the method described in AOAC (2002) in a Nitrogen and Protein analyzer, and crude protein $(\mathrm{CP})$ was calculated as $\mathrm{N} \times 6.25$. Determinations of total phenols (TP) and total tannins (TT) were made following the procedure described by Makkar (2003).

\section{In vitro fermentation, digestibility and methane production}

The rumen fluid was collected from three rumen cannulated Merino sheep fed ad libitum alfalfa hay. It was prepared and purged with $\mathrm{CO}_{2}$ to maintain anaerobic conditions (Grant and Mertens, 1992). After blending, the rumen fluid was transferred to a large glass beaker inside a $39^{\circ} \mathrm{C}$ water bath being continuously purged with $\mathrm{CO}_{2}$ and continuously stirred as recommended by Goering and van Soest (1970). The buffer solution, macro and micro mineral solution were prepared in large volumes and utilized as needed as described in Goering and van Soest (1970).

Gas production was determined as described by Theodorou et al. (1994). Four hundred mg of the ground browse/shrub samples with and without PEG (molecular weight, 6000, analytical grade Sigma-Aldrich) were incubated with $40 \mathrm{~mL}$ of diluted rumen fluid $(15 \mathrm{~mL}$ rumen fluid $+25 \mathrm{~mL}$ culture medium) in serum bottles in a $\mathrm{CO}_{2}$ atmosphere. Two serum bottles containing rumen fluid inoculum were incubated as controls and used to account for gas production in the absence of the substrate. All serum bottles were returned to the incubator and the rotary shaker was turned on at 120 revolutions per minute $(\mathrm{rpm})$. Two replicates of the same browse and four differ-

Table 1 - Mean chemical and phenolic composition of browse plants $\left(\mathrm{g} \mathrm{kg}^{-1} \mathrm{DM}\right)$ used in the study $(\mathrm{n}=3)$.

\begin{tabular}{|c|c|c|c|c|c|c|c|}
\hline Species name & $\mathrm{OM}$ & $\mathrm{CP}$ & NDF & ADF & $\mathrm{ADL}$ & Total phenol & Total tannin \\
\hline \multicolumn{8}{|l|}{ Trees } \\
\hline Acacia erioloba & $939.8^{c}$ & $169.8^{b}$ & $456.3^{c}$ & $391.8^{d}$ & $324.8^{a}$ & $182.4^{\mathrm{d}}$ & $145.4^{d}$ \\
\hline Boscia albitrunca & $924.4^{e}$ & $253.3^{a}$ & $369.2^{f}$ & $292.2^{\mathrm{g}}$ & $128.5^{\mathrm{e}}$ & $24.7^{\mathrm{h}}$ & $9.1^{\mathrm{h}}$ \\
\hline Acacia haematoxylon & $932.8^{d}$ & $131.2^{\mathrm{e}}$ & $533.4^{a}$ & $431.0^{\mathrm{b}}$ & $275.7^{b}$ & $204.1^{c}$ & $163.4^{c}$ \\
\hline Olea europaea & $939.1^{c}$ & $74.9^{j}$ & $355.6^{g}$ & $327.8^{f}$ & $131.3^{\mathrm{e}}$ & $154.9^{f}$ & $73.0^{\mathrm{g}}$ \\
\hline Ziziphus mucronata & $908.9^{\dagger}$ & $157.3^{d}$ & $364.6^{g f}$ & $291.3^{\mathrm{g}}$ & $166.6^{c}$ & $136.2^{\mathrm{g}}$ & $79.4^{\mathrm{g}}$ \\
\hline Terminalia sericea & $948.7^{\mathrm{b}}$ & $97.4^{i}$ & $520.1^{b}$ & $445.7^{a}$ & $105.3^{f}$ & $223.4^{b}$ & $106.8^{f}$ \\
\hline Rhus lancea & $951.0^{\mathrm{a}}$ & $120.3^{h}$ & $454.0^{c}$ & $404.5^{c}$ & $95.0 \mathrm{~g}$ & $226.6 b$ & $197.0^{\mathrm{b}}$ \\
\hline Acacia karroo & $930.9^{d}$ & $124.7^{\mathrm{g}}$ & $427.2^{d}$ & $351.8^{\mathrm{e}}$ & $133.3^{\text {ed }}$ & $217.2^{b}$ & $200.7^{b}$ \\
\hline Prosopis glandulosa & $937.8^{c}$ & $163.5^{c}$ & $403.6^{e}$ & $347.8^{e}$ & $101.8^{\dagger}$ & $171.2^{\mathrm{e}}$ & $132.0^{e}$ \\
\hline Acacia luederitzii & $939.8^{c}$ & $130.6^{4}$ & $460.3^{c}$ & $385.8^{d}$ & $138.8^{d}$ & $314.5^{\mathrm{a}}$ & $298.8^{a}$ \\
\hline Mean & 935.3 & 142.3 & 434.4 & 366.9 & 160.1 & 185.5 & 140.6 \\
\hline SEM & 0.728 & 0.01 & 0.413 & 0.386 & 0.197 & 3.4 & 3.14 \\
\hline \multicolumn{8}{|l|}{ Shrubs } \\
\hline Acacia mellifera & $915.9^{\mathrm{gh}}$ & $203.4^{c}$ & $373.6^{f}$ & $302.1^{\dagger}$ & $80.1^{\mathrm{h}}$ & $54.8^{f}$ & $30.6^{4}$ \\
\hline Acacia hebeclada & $937.1^{d c}$ & $233.0^{b}$ & $401.2^{\mathrm{e}}$ & $390.0^{d c}$ & $97.4^{+}$ & $30.5^{\mathrm{h}}$ & $16.1^{\mathrm{g}}$ \\
\hline Grewia flava & $929.8^{\text {de }}$ & $125.1^{\mathrm{h}}$ & $443.9^{d}$ & $399.5^{c}$ & $105.3^{e}$ & $233.7^{c}$ & $171.3^{c}$ \\
\hline Dichrostachys cinera & $959.5^{\mathrm{a}}$ & $141.5^{\mathrm{e}}$ & $508.9^{a}$ & $376.8^{d}$ & $227.8^{d}$ & $386.5^{a}$ & $319.8^{a}$ \\
\hline Hermannia burchelli & $924.7^{\mathrm{fe}}$ & $177.2^{\mathrm{d}}$ & $369.7^{\dagger}$ & $353.2^{\mathrm{e}}$ & $69.9^{i}$ & $189.3^{\mathrm{d}}$ & $148.3^{d}$ \\
\hline Lycium cinereum & $783.7^{i}$ & $328.9^{a}$ & $363.0^{f}$ & $277.2^{\mathrm{g}}$ & $85.4^{\mathrm{g}}$ & $24.3^{\mathrm{h}}$ & $12.8^{g}$ \\
\hline Monechma genistifolium & $790.5^{i}$ & $83.8^{i}$ & $494.2^{b}$ & $465.1^{\mathrm{a}}$ & $266.2^{\mathrm{b}}$ & $44.9^{\mathrm{g}}$ & $28.2^{f}$ \\
\hline Hermanniato mentosa & $915.0^{\text {fe }}$ & $136.2^{4}$ & $474.9^{c}$ & $426.4^{b}$ & $290.3^{a}$ & $97.3^{\mathrm{e}}$ & $72.1^{\mathrm{e}}$ \\
\hline Monechma incanum & $919.4^{\mathrm{gt}}$ & $130.6^{\mathrm{g}}$ & $449.1^{\mathrm{d}}$ & $350.1^{\mathrm{e}}$ & $232.1^{\mathrm{c}}$ & $307.6^{\mathrm{b}}$ & $282.5^{b}$ \\
\hline Mean & 892.8 & 173.3 & 430.9 & 371.2 & 161.6 & 152.1 & 120.2 \\
\hline SEM & 2.5 & 0.01 & 0.356 & 0.499 & 0.14 & 3.08 & 2.9 \\
\hline
\end{tabular}

Means with different superscript (letters) across the column for each parameter are significantly $(p<0.05)$ different; $\mathrm{OM}=$ organic matter; $\mathrm{CP}=\mathrm{crude}$ protein; $\mathrm{ADF}$ $=$ acid detergent fibre; NDF = neutral detergent fibre; $A D L=$ acid detergent lignin . 
ent cycles were executed for every browse sample studied. Fermentation was terminated after $48 \mathrm{~h}$ by removing the serum bottles from the incubator and placed on ice. Supernatants were taken immediately, pipetted and stored at -20 ${ }^{\circ} \mathrm{C}$ until analyzed for ammonia nitrogen $\left(\mathrm{NH}_{3}-\mathrm{N}\right)(\mathrm{McD}$ onald et al., 1960) and volatile fatty acid (VFA) (Ottenstein and Bartley, 1971). The in vitro organic matter digestibility (IVOMD) was done according to Tilley and Terry (1963), as modified Engels and van der Merwe (1967).

Methane production was measured from duplicate bottles incubated for each browse by taking gas samples at $2,12,24$, and $48 \mathrm{~h}$ and analyzing the methane concentration using gas chromatography $(\mathrm{GC})$ equipped with a stainless steel column packed with Porapak- $Q$ and a Flame Ionization Detector. The GC was calibrated with standard $\mathrm{CH}_{4}$ before injection of the sample. Gas produced from each bottle at various times was recorded and samples of the gas were taken using a Hamilton syringe. One $\mathrm{mL}$ of sampled gas produced was injected manually (pull and push method of sample injection) into the GC.

Data were statistically analyzed using the general linear model (GLM) procedure from SAS (Statistical Analysis System, Version 9.2), considering each incubation run as a block for species. The average of the two bottles was considered as data from an experimental unit. The differences between means were determined using Duncan's multiple range test.

\section{Results}

\section{Chemical composition}

The browse studied showed significant variations in chemical and phenolic composition (Table 1). In this study, forage from shrub species had a higher mean value of crude protein concentration $\left(173.3 \mathrm{~g} \mathrm{~kg}^{-1}\right.$ $\mathrm{DM})$ than tree species (142.3 $\left.\mathrm{g} \mathrm{kg}^{-1} \mathrm{DM}\right)$. Among the tree forage species, Boscia albitrunca had the highest and Olea europaea the lowest CP concentrations. Within the shrub species, Lycium cinereum had the highest CP concentration while Monechma genistifolium had the lowest $\mathrm{CP}$ concentration. Acacia haematoxylon had the highest NDF and ADF concentrations while Acacia erioloba had the highest ADL concentrations among the tree species. The highest concentrations for NDF, ADF and ADL were found in Dichrostachys cinerea, Monechma genistifolium, and Hermannia tomentosa among shrubs, respectively.

Acacia luederitzii and Dichrostachys cinerea had the highest concentration of total phenols and total tannins among the tree and shrub species, respectively. Among the tree species, Boscia albitrunca had the lowest phenolic concentration, while Lycium cinereum had the lowest concentration of total phenols and total tannins.

\section{In vitro gas and methane production}

The in vitro gas and methane production of browse species studied at 12 and $24 \mathrm{~h}$ of incubation ( \pm PEG) are shown in Table 2. Both in the presence and absence of PEG there was a significant $(p<0.05)$ variation amongst browse species in terms of gas and methane production. Inclusion of PEG in fermentation of tropical browses resulted in a significant $(p<0.001)$ increase in gas and methane profile particularly in browse forage species with a high secondary phenolic content. However, no effects of PEG on the gas and methane profiles of lower concentration tannin plants, such as Acacia mellifera, Acacia hebeclada and Lycium cinereum were detected. In the current study, the volume of methane produced at different incubation periods differed significantly $(p$ $<0.001$ ) between the browse species, depending on the concentration of tannin. In the presence of tannins, Rhus lancea and Acacia luederitzii showed significantly low methane volumes among tree browses, while Lycium cinereum and Monechma incanum presented significantly low methane volumes among shrub browses.

\section{Feed digestibility and certain rumen related parameters}

The IVOMD, total VFA and methane expressed in mass are shown in Table 3. The IVOMD differed $\mid p<$ 0.05) within trees and shrubs both in the presence and absence of PEG. As expected, browses with high tannin concentrations were found to be low in digestibility; however, inclusion of PEG significantly improved their digestibility. Among the tree foliage, Boscia albitrunca and Ziziphus mucronata have the highest IVOMD values both in the presence and absence of PEG. Among shrubs, Lycium cinereum showed the highest value of IVOMD both in the presence and absence of PEG.

The VFA and $\mathrm{NH}_{3}-\mathrm{N}$ concentrations differed significantly $(p \leq 0.001)$ between trees and shrubs species. The absence of tannin significantly increased the concentration of VFA. Ziziphus mucronata showed the highest concentration of VFA in both the presence and absence of PEG among tree browses, while Hermannia mentosa showed the highest VFA concentration among shrub browses both in the presence and absence of PEG.

The recorded $\mathrm{NH}_{3}-\mathrm{N}$ concentrations were the highest for Boscia albitrunca of the tree browses and for the shrubs, Acacia mellifera without PEG. Acacia karroo and Monechma incanum had the lowest $\mathrm{NH}_{3}-\mathrm{N}$ concentrations among trees and shrubs, respectively, with PEG. With the inclusion of PEG, Acacia karroo and Lycium cinereum produced the highest concentrations of $\mathrm{NH}_{3}-\mathrm{N}$ among trees and shrubs, respectively.

The correlation coefficients of ruminal fermentation parameters (IVOMD, $\mathrm{CH}_{4}$ ) with the chemical composition and phenolic compounds of the trees and shrubs are presented in Table 4. Significantly $(p<0.05)$, positive correlations were observed between IVOMD and nitrogen and NFC content. There were significant $(p<0.001)$ negative correlations of IVOMD with fiber components (ADF, cellulose, hemi-cellulose) and phenolic compounds (total phenol, total tannin, condensed tannin and hydrolysable tannin). Methane production showed a significant $(p<0.001)$ negative correlation with phenolic compounds (TP, TT, CT and $\mathrm{HT}$ ) and positive correlation with fiber components. 
Table 2 - Mean gas production and methane production ( $\left.\mathrm{LL} \mathrm{g}^{-1} \mathrm{DM}\right)$ of browse plants studied $(\mathrm{n}=8)$.

\begin{tabular}{|c|c|c|c|c|c|c|c|c|}
\hline \multirow{3}{*}{ Scientific name } & \multicolumn{4}{|c|}{ Gas volume } & \multicolumn{4}{|c|}{ Methane gas } \\
\hline & \multicolumn{2}{|c|}{$12 \mathrm{~h}$} & \multicolumn{2}{|c|}{$24 \mathrm{~h}$} & \multicolumn{2}{|c|}{$12 \mathrm{~h}$} & \multicolumn{2}{|c|}{$24 \mathrm{~h}$} \\
\hline & $\mathrm{PEG}+$ & PEG - & $\mathrm{PEG}+$ & PEG - & $\mathrm{PEG}+$ & PEG - & $\mathrm{PEG}+$ & PEG - \\
\hline \multicolumn{9}{|l|}{ Trees } \\
\hline Acacia erioloba & $116.8^{\mathrm{d}}{ }_{1}$ & $84.50^{\mathrm{d}}{ }_{2}$ & $135.5^{\mathrm{dc}}{ }_{1}$ & $106.5^{\mathrm{e}}$ & $17.25^{c}{ }_{1}$ & $9.45_{2}^{d}$ & $39.5^{\mathrm{cbd}}$ & $28.25^{\mathrm{d}}{ }_{2}$ \\
\hline Boscia albitrunca & $150.0^{\mathrm{b}}{ }_{1}$ & $120.0_{2}^{\mathrm{b}}$ & $182.0^{\mathrm{a}}{ }_{1}$ & $154.3^{\mathrm{b}}{ }_{2}$ & $22.58^{\mathrm{b}}{ }_{1}$ & $19.50^{\mathrm{b}}{ }_{1}^{\mathrm{c}}$ & $64.5^{\mathrm{a}}{ }_{1}$ & $63.25^{\mathrm{a}}{ }_{1}$ \\
\hline Acacia haematoxylon & $96.00_{1}^{\dagger}$ & $60.25_{2}^{\dagger}$ & $115.5_{1}^{\dagger}$ & $71.75^{2}$ & $15.33^{\mathrm{c}}{ }_{1}$ & $8.00_{2}^{1}$ & $34.0_{1}^{1 \mathrm{ced}}$ & $20.00^{e^{1}}$ \\
\hline Olea europaea & $101.5_{1}^{\dagger}$ & $101.3^{\mathrm{e}^{2}}$ & $140.5^{d c}$ & $137.8_{1}^{c}$ & $8.83^{\mathrm{d}}$ & $17.20^{c}{ }_{1}$ & $25.5^{\mathrm{e}}{ }_{2}$ & $50.0^{\mathrm{b}}{ }_{1}^{\mathrm{c}}$ \\
\hline Ziziphus mucronata & $167.8^{\mathrm{a}}{ }_{1}$ & $139.3_{2}^{\mathrm{a}}$ & $188.3^{\mathrm{a}}{ }_{1}$ & $172.3^{\mathrm{a}}$ & $31.25^{\mathrm{a}}{ }_{1}$ & $25.75^{\mathrm{a}}{ }_{1}$ & $64.00^{\mathrm{a}}{ }_{1}$ & $63.75^{\mathrm{a}}{ }_{1}$ \\
\hline Terminalia sericea & $96.00_{1}^{f}$ & $55.50_{2}^{\dagger}$ & $117.5_{1}^{\dagger}$ & $68.25 \mathrm{~g}$ & $15.70^{c}{ }_{1}$ & $6.58_{2}^{\dagger}$ & $33.50^{\text {ced }}$ & $17.95^{2}{ }_{2}$ \\
\hline Rhus lancea & $125.8^{\mathrm{dc}}{ }_{1}$ & $36.75 \mathrm{~g}$ & $157.5^{\mathrm{b}}{ }_{1}$ & $54.50^{\mathrm{h}}$ & $18.63^{\mathrm{cb}}{ }_{1}$ & $1.63_{2}^{\mathrm{h}}$ & $43.50^{\mathrm{cb}}{ }_{1}$ & $7.08^{2}$ \\
\hline Acacia karroo & $130.0^{c}{ }_{1}$ & $72.00 \mathrm{e}_{2}^{2}$ & $145.3^{c}{ }_{1}$ & $92.00_{2}^{\mathrm{f}}$ & $23.00^{\mathrm{b}}{ }_{1}^{\mathrm{T}}$ & $3.88_{2}$ & $45.00^{\mathrm{b}}{ }_{1}^{\mathrm{t}}$ & $12.25_{2}^{\dagger}$ \\
\hline Prosopis glandulosa & $106.5^{\mathrm{fe}}{ }_{1}$ & $103.8^{c}{ }_{1}$ & $121.0^{\mathrm{fe}}$ & $120.3_{1}^{\mathrm{d}}$ & $17.70^{c}{ }_{1}$ & $16.20^{c}{ }_{1}$ & $40.50^{\text {ed }}{ }_{1}$ & $30.5^{c}{ }_{2}$ \\
\hline Acacia luederitzii & $116.3^{\mathrm{de}}{ }_{1}$ & $36.00 \mathrm{~g}$ & $130.8^{\mathrm{de}}$ & $44.75_{2}^{i}$ & $22.00^{\mathrm{b}}{ }_{1}$ & $0.13_{2}{ }_{2}$ & $43.25^{\mathrm{cb}}{ }_{1}$ & $1.58_{2}^{\mathrm{h}}$ \\
\hline Mean & 120.5 & 81.00 & 143.5 & 102.3 & 19.23 & 10.83 & 43.75 & 39.5 \\
\hline SEM & 3.30 & 2.88 & 3.90 & 3.03 & 0.58 & 0.18 & 1.30 & 0.30 \\
\hline \multicolumn{9}{|l|}{ Shrubs } \\
\hline Acacia mellifera & $75.30^{\mathrm{e}}$ & $92.25^{d}$ & $122.5^{d}$ & $104.3^{c}{ }_{2}$ & $130.8^{\mathrm{e}}$ & $9.38^{c}$ & $35.25^{\mathrm{e}}$ & $24.08^{\mathrm{de}}$ \\
\hline Acacia hebeclada & $138.3^{\mathrm{a}}{ }_{1}$ & $134.5^{\mathrm{a}}$ & $161.3^{\mathrm{a}}{ }_{1}$ & $158.5^{a}{ }_{1}$ & $27.25^{c}{ }_{1}$ & $24.20^{\mathrm{b}}{ }_{1}$ & $63.0^{\mathrm{b}}{ }_{1}$ & $51.5^{\mathrm{b}}{ }_{2}$ \\
\hline Grewia flava & $108.5^{\mathrm{c}}$ & $55.50_{2}^{f}$ & $141.8^{1}{ }_{1}$ & $85.75^{\mathrm{e}}$ & $19.63^{d}$ & $8.25^{\mathrm{d}}$ & $48.25^{d}$ & $28.25^{\mathrm{d}}$ \\
\hline Dichrostachys cinera & $109.3^{c}{ }_{1}$ & $58.25_{2}^{\dagger}$ & $134.3^{c}{ }_{1}$ & $71.75_{2}^{\dagger}$ & $20.75^{d}{ }_{1}$ & $2.58^{\mathrm{e}}$ & $45.25^{\mathrm{de}}{ }_{1}$ & $7.45^{2}{ }_{2}$ \\
\hline Hermannia burchelli & $139.0^{\mathrm{a}}$ & $119.3_{2}^{\mathrm{b}}$ & $162.0^{1}{ }_{1}^{1}$ & $152.3^{\mathrm{a}}{ }_{2}$ & $31.50^{\mathrm{b}}{ }_{1}$ & $26.0_{2}^{\mathrm{a}}$ & $65.75^{\mathrm{b}}{ }_{1}^{\mathrm{t}}$ & $64.00^{\mathrm{a}}{ }_{1}^{2}$ \\
\hline Lycium cinereum & $69.00_{1}^{f}$ & $68.75^{\mathrm{e}}$ & $87.75^{\mathrm{e}}$ & $79.50_{2}^{\mathrm{e}}$ & $1.08_{1}^{\dagger}$ & $0.50_{2}^{f}$ & $1.58_{1}^{\dagger}$ & $1.825^{\dagger}$ \\
\hline Monechma genistifolium & $92.50^{d}{ }_{1}$ & $86.00^{d}$ & $105.8^{\mathrm{d}}{ }_{1}$ & $103.8^{\mathrm{d}}{ }_{1}$ & $25.25^{c}{ }_{1}$ & $24.63^{b}$ & $52.25^{c}{ }_{1}$ & $42.00^{c}{ }_{2}$ \\
\hline Hermanniato mentosa & $126.5^{\mathrm{b}}{ }_{1}$ & $100.5_{2}^{c}$ & $151.5^{\mathrm{b}}{ }_{1}$ & $132.8^{\mathrm{b}}{ }_{2}$ & $35.75^{\mathrm{a}}{ }_{1}$ & $24.95^{\mathrm{b}}{ }_{2}$ & $77.25^{\mathrm{a}}{ }_{1}$ & $58.0^{\text {ba }}{ }_{2}^{2}$ \\
\hline Monechma incanum & $134.8^{\mathrm{a}}{ }_{1}$ & $59.75_{2}^{\dagger}$ & $164.0^{\mathrm{a}}{ }_{1}$ & $73.25_{2}^{\dagger}$ & $36.75^{\mathrm{a}}{ }_{1}$ & $1.50^{\mathrm{fe}}{ }_{2}$ & $77.00^{\mathrm{a}}{ }_{1}$ & $4.45^{\mathrm{fe}}{ }_{2}$ \\
\hline \multirow{2}{*}{ Mean } & 110.3 & 86.00 & 136.8 & 106.8 & 23.45 & 13.55 & 51.75 & 31.25 \\
\hline & 2.8 & 2.58 & 2.93 & 3.13 & 0.15 & 0.40 & 0.36 & 1.063 \\
\hline
\end{tabular}

Means with different superscript $(a, b, c, d, e, f, g, h)$ across the column for each parameter are significantly $(p<0.05)$ different; PEG $=$ Polyethylene glycol; PEG $(-)$ denotes presence of tannin, PEG (+) denotes absence of tannin.

\section{Discussion}

The Thorny Kalahari Dune Bush veldt is characterized by irregular rainfall all through the year and intense water stress, which results in limited herbaceous flora existing in this part of Africa for most of the year. Thus, browse tree and shrub foliages are the main feed sources for ruminants. In the current study, except for Olea europaea, Terminalia sericea and Monechma genistifolium, the $\mathrm{CP}$ values observed were within the optimal range of 110-160 g CP kg-1 DM recommended by the NRC (2001) for maintenance requirements of small ruminants. In addition, results obtained in this study for browse species, phenolic components were similar to the results reported by Jayanegara et al. (2011). Although the phenolic concentrations were slightly high, these browse species can be a potential supplement during times of drought. Addition of PEG could overcome adverse effects of high tannins on nutrient availability, as indicated by cumulative gas production, IVOMD, VFA and $\mathrm{NH}_{3}-\mathrm{N}$ concentrations. As observed in this study for Rhus lancea, Acacia luederitzii and Monechma incanum, inclusion of PEG during the incubation of tannin-rich plants led to an increase in gas production of $100 \%$ and this has the potential to increase rumen fermentation. Feed fermentation in the rumen and digestibility determine nutritive values of browse and these parameters are further influenced by chemical and phenolic compositions. High gas production indicated more fermentation which supported high rumen microbial production (van Soest, 1994). In the current study, the main factors affecting gas production and IVOMD of browse were high fiber and tannin concentrations. In agreement with current findings, studies done on different tropical browses have showed negative effects of plant phenolic compounds on the fermentation rate and level of digestion (Bhatta et al., 2009; Sebata et al., 2011). The negative effect of tannins on fermentation and digestion could be related to the formation of tannin-carbohydrate and tannin-protein complexes that are less degradable or to its toxicity to rumen microbes (Bhatta et al., 2009). Moreover, it acted as a toxicant to methanogens, reduced acetate and butyrate production (i.e. reduced fiber degradation) or caused a decline in organic matter (OM) digestion (Patra and Saxena, 2011).

Production of methane is a sink for hydrogen in the rumen during the process of utilization of feed energy. However, with fermentation of tannin rich plants, its bacteriocidal and bacteriostatic effects on the rumen microbes, and inactivation of its enzymes, greatly suppresses fermentation and this could result in a decrease of $\mathrm{CH}_{4}$ production (Patra and Saxena, 2011). In the current study, the presence of tannin decreased methane production in 
Table 3 - Mean volatile fatty acid (mmol $\mathrm{L}^{-1}$ ) production, ammonia N (mg L-1), in vitro organic matter digestibility $\left(\mathrm{g} \mathrm{kg}^{-1} \mathrm{DM}\right)$ and methane (CH4) production in mass (g kg-1 IVOMD) from the browse plants studied after $24 \mathrm{~h}$ of incubation.

\begin{tabular}{|c|c|c|c|c|c|c|c|c|}
\hline \multirow{2}{*}{ Species names } & \multicolumn{2}{|c|}{ Total VFA } & \multicolumn{2}{|c|}{$\mathrm{NH}_{3}-\mathrm{N}$} & \multicolumn{2}{|c|}{ IVOMD } & \multicolumn{2}{|c|}{$\mathrm{CH} 4$} \\
\hline & PEG + & PEG - & PEG + & PEG - & PEG + & PEG - & $\mathrm{PEG}+$ & PEG - \\
\hline \multicolumn{9}{|l|}{ Trees } \\
\hline Acacia erioloba & $99.6_{1}^{i}$ & $95.0_{2}^{\mathrm{h}}$ & $20.5_{2}^{\dagger}$ & $33.3_{1}^{b}$ & $44.0^{\mathrm{d}}{ }_{1}$ & $44.6_{1}^{c}$ & $21.0_{1}^{\mathrm{b}}$ & $10.5_{2}^{\mathrm{fe}}$ \\
\hline Boscia albitrunca & $113.9^{c}{ }_{1}$ & $106.7^{c}{ }_{2}$ & $22.8^{\mathrm{b}}{ }_{2}$ & $36.6^{\mathrm{a}}{ }_{1}$ & $62.2^{\mathrm{a}}{ }_{1}$ & $62.1^{\mathrm{a}}{ }_{1}$ & $17.2_{1}^{\mathrm{ed}}$ & $15.4^{\mathrm{ba}}{ }_{2}$ \\
\hline Acacia haematoxylon & $100.1_{1}^{\mathrm{h}}$ & $97.2^{\mathrm{g}}$ & $21.7{ }_{2}{ }_{2}$ & $25.1_{1}^{\mathrm{e}}$ & $31.0_{1}^{\dagger}$ & $30.9^{d}{ }_{1}$ & $25.3^{\mathrm{a}}{ }_{1}$ & $14.0_{2}^{\mathrm{bc}}$ \\
\hline Olea europaea & $109.7_{1}^{d}$ & $106.5^{d}$ & $19.0_{2}^{2}$ & $22.3^{\mathrm{g}}{ }_{1}$ & $53.2^{\mathrm{b}}{ }_{1}$ & $49.2^{\mathrm{bc}}{ }_{2}$ & $11.9_{2}^{\dagger}$ & $13.1_{1}^{\mathrm{dc}}$ \\
\hline Ziziphus mucronata & $156.3^{\mathrm{a}}{ }_{1}$ & $119.7^{\mathrm{a}}{ }_{2}$ & $20.7 \mathrm{e}_{2}$ & $29.2^{\mathrm{c}}{ }_{1}$ & $63.2^{\mathrm{a}}{ }_{1}$ & $64.7{ }_{1}{ }_{1}$ & $16.1_{1}^{\mathrm{e}}$ & $12.4_{2}^{\mathrm{d}}$ \\
\hline Terminalia sericea & $103.0_{1}$ & $82.1{ }_{2}$ & $20.2^{\mathrm{g}}{ }_{2}$ & $22.8_{1}^{\dagger}$ & $38.5_{1}$ & $24.9{ }_{2}$ & $19.2^{\mathrm{cbd}}$ & $15.7^{\mathrm{a}}{ }_{2}$ \\
\hline Rhus lancea & $115.5^{\mathrm{b}}$ & $104.9 e_{2}$ & $21.0_{1}^{\mathrm{d}}$ & $18.8^{\mathrm{h}}$ & $36.7 e_{1}$ & $23.0^{d}$ & $18.6^{\text {cd }}{ }_{1}$ & $11.8^{\mathrm{de}}$ \\
\hline Acacia karroo & $108.1_{1}^{f}$ & $98.6_{2}^{4}$ & $26.9{ }_{1}$ & $16.1_{2}^{\mathrm{j}}$ & $48.8^{c}$ & $56.1^{\text {ba }}$ & $19.7_{1}^{\mathrm{cb}}$ & $4.72_{2}^{\mathrm{g}}$ \\
\hline Prosopis glandulosa & $108.5^{\mathrm{e}}$ & $110.9^{b}{ }_{1}$ & $19.4_{2}^{i}$ & $25.7_{1}^{\mathrm{d}}$ & $55.4^{\mathrm{b}}{ }_{1}$ & $56.5^{\mathrm{ba}}{ }_{1}$ & $13.8_{1}^{\dagger}$ & $10.1_{2}^{\dagger}$ \\
\hline Acacia luederitzii & $99.0_{1}$ & $84.0_{2}$ & $19.9^{\mathrm{h}}$ & $17.2^{i}$ & $43.3_{1}^{d}$ & $44.9 \mathrm{c}$ & $17.5^{\text {ced }}$ & $4.04{ }_{2}$ \\
\hline Mean & 111.4 & 100.6 & 2 & 24.7 & 47.6 & 45.7 & 18.1 & 11.2 \\
\hline SEM & 1.14 & 1.58 & 0.51 & 0.72 & 0.45 & 0.58 & 0.12 & 0.09 \\
\hline \multicolumn{9}{|l|}{ Shrubs } \\
\hline Acacia mellifera & $104.3^{\mathrm{h}}{ }_{1}$ & $107.0^{\mathrm{e}}$ & $21.5^{\mathrm{g}}$ & $29.9^{a}$ & $57.1_{2}^{c}$ & $59.2^{\mathrm{cd}}{ }_{1}$ & $12.2^{\mathrm{d}}{ }_{1}$ & $12.7_{2}^{\mathrm{b}}$ \\
\hline Acacia hebeclada & $118.0^{\mathrm{b}}{ }_{1}$ & $115.6^{\mathrm{b}}$ & $22.4_{2}^{\mathrm{b}}$ & $26.2^{\mathrm{c}}{ }_{1}$ & $61.8_{1}^{\mathrm{b}}$ & $61.1_{1}^{\mathrm{cb}}$ & $13.0^{\mathrm{d}}{ }_{1}$ & $10.0^{c}{ }_{2}$ \\
\hline Grewia flava & $106.7^{\mathrm{g}}$ & $101.7^{\mathrm{h}}$ & $22.0^{\mathrm{d}}$ & $28.5^{\mathrm{b}}{ }_{1}$ & $32.5^{\mathrm{g}}$ & $30.9 \mathrm{~g}$ & $22.0^{\mathrm{b}}$ & $18.3^{\mathrm{a}}$ \\
\hline Dichrostachys cinera & $111.8^{d}$ & $83 . \mathrm{i}_{2}$ & $21.2^{\mathrm{h}}{ }_{1}$ & $20.0^{\mathrm{h}}{ }_{1}$ & $33.5^{\mathrm{g}}$ & $31.0 \mathrm{~g}_{2}$ & $25.7_{1}^{\mathrm{a}}$ & $7.21_{2}^{\mathrm{d}}$ \\
\hline Hermannia burchelli & $107.0_{1}^{f}$ & $107.7^{\mathrm{d}}$ & $21.5_{1}^{\dagger}$ & $22.3_{1}^{f}$ & $56.2^{c}$ & $63.5^{\mathrm{b}}{ }_{1}$ & $17.5^{\mathrm{c}}$ & $12.1^{\mathrm{b}}$ \\
\hline Lycium cinereum & $107.9 \mathrm{e}_{1}$ & $105.7_{1}^{\dagger}$ & $22.7_{2}$ & $25.3^{\mathrm{d}}{ }_{1}$ & $77.1^{\mathrm{a}}$ & $81.1^{\mathrm{a}}{ }_{1}$ & $3.54_{1}^{\mathrm{e}}$ & $2.16_{2}^{\dagger}$ \\
\hline Monechma genistifolium & $103.5_{1}^{i}$ & $103.1_{1}^{\mathrm{g}}$ & $16.4_{2}^{i}$ & $21.5^{\mathrm{g}}{ }_{1}$ & $52.5 d_{2}$ & $57.1_{1}^{\mathrm{d}}$ & $18.0^{c}$ & $12.9^{\mathrm{b}}$ \\
\hline Hermanniato mentosa & $133.1_{1}^{\mathrm{a}}$ & $116.2^{\mathrm{a}}{ }_{2}$ & $22.3_{2}$ & $24.0 e_{1}$ & $40.9_{2}^{f}$ & $47.3_{1}$ & $25.6^{\mathrm{a}}$ & $17.4^{\mathrm{a}}{ }_{2}$ \\
\hline Monechma incanum & $114.8_{1}^{c}$ & $114.0^{c}$ & $21.9_{1}^{\dagger}$ & $19.9_{2}^{i}$ & $47.6 \mathrm{e}_{1}$ & $38.7_{2}^{\dagger}$ & $20.7^{\mathrm{b}}$ & $5.42^{\mathrm{e}}{ }_{2}$ \\
\hline Mean & 111.9 & 106.0 & 2.13 & 24.7 & 51.0 & 52.2 & 17.6 & 10.9 \\
\hline SEM & 3.54 & 5.12 & 0.57 & 0.68 & 0.58 & 0.36 & 0.17 & 0.089 \\
\hline
\end{tabular}

Means with different superscript (letters) within a column for each parameter are significantly $(p<0.05)$ different; $P E G=$ Polyethylene glycol; PEG $(-)$ denotes presence of tannin, PEG (+) denotes absence of tannin. VFA = volatile fatty acids; IVOMD = in vitro organic matter digestibility.

Table 4 - Correlation coefficients $(r)$ between in vitro fermentation parameters with chemical composition and phenolic compounds of browse plants studied.

\begin{tabular}{|c|c|c|c|c|c|}
\hline & IVOMD & TVFA & $\mathrm{NH}_{3}-\mathrm{N}$ & $\mathrm{GP}_{24}$ & $\mathrm{CH}_{4}$ \\
\hline \multicolumn{6}{|c|}{ Chemical composition } \\
\hline Ash & 0.00043 & 0.40475 & 0.30581 & 0.43446 & 0.38066 \\
\hline $\mathrm{OM}$ & 0.00043 & 0.40475 & 0.30581 & 0.43446 & 0.38066 \\
\hline $\mathrm{CP}$ & $0.66639^{*}$ & 0.28331 & $0.50042^{*}$ & 0.47026 & 0.08677 \\
\hline NDFN & 0.0054 & -0.31476 & -0.2924 & -0.3473 & -0.46133 \\
\hline NDF & $-0.74652^{*}$ & $-0.5932^{*}$ & -0.5304 & $-0.67893^{*}$ & -0.3723 \\
\hline ADF & $-0.63965^{*}$ & -0.38326 & -0.34233 & $-0.50149^{*}$ & -0.07653 \\
\hline ADL & -0.27028 & -0.0922 & 0.04748 & -0.18242 & -0.00323 \\
\hline NFC & 0.05584 & 0.01108 & -0.01605 & 0.06941 & -0.11949 \\
\hline \multicolumn{6}{|c|}{ Phenolic components } \\
\hline TP & $-0.69493^{*}$ & $-0.5631^{*}$ & $-0.55093^{*}$ & $-0.73452^{*}$ & $-0.63429 *$ \\
\hline TT & $-0.60308^{*}$ & $-0.4968^{*}$ & $-0.58449^{*}$ & $-0.7401^{*}$ & $-0.67445^{*}$ \\
\hline CT & $-0.56258^{*}$ & $-0.47298^{*}$ & $-0.58643^{*}$ & $-0.73431^{*}$ & $-0.67601^{*}$ \\
\hline HT & $-0.61957^{*}$ & $-0.50323^{*}$ & $-0.56955^{*}$ & $-0.72738^{*}$ & $-0.65773^{*}$ \\
\hline
\end{tabular}

$\mathrm{OM}=$ organic matter; $\mathrm{CP}=$ crud protein; NDFN= Nitrogen in neutral detergent fiber; NDF = neutral detergent fiber; $A D F=$ acid detergent fibre; $A D L=$ acid detergent lignin; NFC = non-fibre carbohydrates; TP = total phenols; TT = total tannins; CT = condensed tannins; HT = hydrolysed tannins; IVOMD = in vitro organic matter digestibility; TVFA = total volatile fatty acids; $\mathrm{NH}_{3}-\mathrm{N}$ - rumen ammonia; $\mathrm{GP}_{24}$. gas production; $\mathrm{CH}_{4}$ - methane.

all the browse species. The decrease in $\mathrm{CH}_{4}$ production with the inclusion of tannin in ruminant diets was similarly reported by several researchers (Sebata et al., 2011; Sultan et al., 2012). In addition, with an increase in tannin concentration in browse species, a reduction effect on methane production was found. The impact of tannins on methane production varies with tannin chemical structure (plant origin) as well as with its concentration.

In tropical ruminant production systems, it is also very important that systematic and strategic supplemen- 
tation of these forages in a mixed diet should be the way forward in their utilization. In such a way it is possible to attain a maximal depressing effect on enteric $\mathrm{CH}_{4}$ production with minimal detrimental effect on rumen fermentation characteristics of poor quality roughage based diets. This can also insure the best option of utilization of these browses in all systems of livestock production.

\section{Conclusion}

From the results obtained in this study, variations were observed in the fermentation of trees and shrubs as well as in methane gas production. For example, tree forage (Rhus lancea and Acacia luederitzii) and shrub forage (Dichrostachys cinera and Monechma incanum) decreased methane and gas production significantly and it seems that Acacia luederitzii and Monechma incanum have a prolonged effect on $\mathrm{CH}_{4}$ production. The substantial amount of CP content of certain species coupled with anti-methanogenic effect during fermentation, would offer farmers and pastoralists farming in sub-Sahara Africa an opportunity to use some of the browses for reducing $\mathrm{CH}_{4}$ production. However, further studies need to be undertaken to determine the variation in the efficacy of the browse samples collected in different seasons in reducing $\mathrm{CH}_{4}$ and mechanisms to integrate these browses to complement low quality feeds for different ruminant groups.

\section{Acknowledgments}

The research leading to these results received funding from the European Community's Framework Programme (FP7/2007-2013) under the grant agreement No. 266018 ANIMALCHANGE. The authors are also grateful for co-funding from the South African Department of Science and Technology. We also would like to thank the Theart family for permitting us access to their property and assistance offered during browse sample collection in the Kalahari district.

\section{References}

Association of Official Analytical Chemists [AOAC]. 2002. Official Methods of Analysis. 17ed. AOAC, Arlington, VA, USA.

Bhatta, R.; Uyeno, Y.; Tajima, K.; Takenaka, A.; Yabumoto, Y.; Nonaka, I.; Enishi, O.; Kurihara, M. 2009. Difference in the nature of tannins on in vitro ruminal methane and volatile fatty acid production and on methanogenic archaea and protozoal populations. Journal of Dairy Science 92: 5512-5522.

Engels, E.; van der Merwe, F.J.1967. Application of an in vitro technique to South African forages with special reference to the effect to certain factors on the results. South African Journal of Agricultural Science 10: 983-992.

Goering, H.K.; van Soest, P.J. 1970. Forage Fiber Analyses: Apparatus, Reagents, Procedures, and some Applications. ARSUSDA, Washington, DC, USA. (USDA Agricultural Handbook, 379 ).
Grant, R.J.; Mertens, D.R. 1992. Impact of in vitro fermentation techniques upon kinetics of fiber digestion. Journal of Dairy Science 75: 1263-1272.

Jayanegara, A.; Wina, E.; Soliva, C.R.; Marquardt, S.; Kreuzera, M.; Leiber, F. 2011. Dependence of forage quality and methanogenic potential of tropical plants on their phenolic fractions as determined by principal component analysis. Animal Feed Science and Technology 163: 231-243.

National Research Council. [NRC]. 2001. Nutrient Requirements of Sheep. 7ed. National Academy Press, Washington, DC, USA

Makkar, H.P.S. 2003. Quantification of Tannins in Tree and Shrub Foliage: A Laboratory Manual. Kluwer Academic, Dordrecht, The Netherlands.

McDonald, P.; Stirling, A.C.; Henderson, A.R.; Dewar, W.A.; Stark, G.H.; Davie, W.G.; MacPherson, H.T.; Reid, A.M.; Salter, J. 1960. Studies on ensilage. Edinburgh School of Agriculture, Edinburgh, Scotland, UK. (Technical Bulletin, 24).

Mueller-Harvey, I. 2006. Unraveling the conundrum of tannins in animal nutrition and health. Journal of the Science of Food and Agriculture 86: 2010-2037.

Ottenstein, D.M.; Bartley, D.A. 1971. Separation of free acids $\mathrm{C}_{2}-$ $\mathrm{C}_{5}$ in diluted aqueous solution column technology. Journal of Chromatography Science 9: 673-681.

Patra, A.K.; Saxena, J. 2011. Exploitation of dietary tannins to improve rumen metabolism and ruminant nutrition. Journal of the Science of Food and Agriculture 91: 24-37.

Puchala, R.; Min, B.R.; Goetsch, A.L.; Sahlu, T. 2005. The effect of a condensed tannin-containing forage on methane emission by goats. Journal of Animal Science 83: 182-186.

Sebata, A.; Ndlovu, L.R.; Dube, J.S. 2011. Chemical composition, in vitro dry matter digestibility and in vitro gas production of five woody species browsed by Matebele goats (Capra hircus L.) in a semi-arid savanna, Zimbabwe. Animal Feed Science and Technology 170: 122-125.

Sultan, S.; Kushwaha, B.P.; Naga, S.K.; Mishra, A.K.; Singh, A.; Anele, U.Y. 2012. In vitro ruminal fermentation, protein and carbohydrate fractionation, methane production and prediction of twelve commonly used Indian green forages. Animal Feed Science and Technology 178: 2-11.

Tavendale, M.H.; Meagher, L.P.; Pacheco, D.; Walker, N.; Attwood, G.T.; Sivakumaran, S. 2005. Methane production from in vitro rumen incubations with Lotus pedunculatus and Medicago sativa, and effects of extractable condensed tannin fractions on methanogenesis. Animal Feed Science and Technology 123124: 403-419.

Theodorou, M.K.; Williams, B.A.; Dhanoa, M.S.; McAllan, A.B.; France, J. 1994. A simple gas production method using pressure transducers to determine the fermentation kinetics of ruminant feed. Animal Feed and Science Technology 48: 185-197.

Tilley, J.M.A.; Terry, R.A. 1963. A two-stage technique for the in vitro digestion of forage crops. Journal of British Grassland Society 18: 104-111.

van Soest, P.J. van. 1994. Nutritional Ecology of the Ruminant. 2ed. Cornell University Press, Ithaca, NY, USA

van Soest, P.J. van; Robertson, J.B.; Lewis, B.A. 1991. Methods for dietary fiber, neutral detergent fiber, and non-starch polysaccharides in relation to animal nutrition. Journal of Dairy Science 74: 3583-3597. 